\title{
Developmental Changes in Calcium Channel Types Mediating Central Synaptic Transmission
}

\author{
Shinichi Iwasaki, ${ }^{1}$ Akiko Momiyama, ${ }^{2}$ Osvaldo D. Uchitel, ${ }^{3}$ and Tomoyuki Takahashi ${ }^{1}$ \\ ${ }^{1}$ Department of Neurophysiology, University of Tokyo Faculty of Medicine, Tokyo 113-0033, Japan, 2Laboratory of \\ Cerebral Structure, National Institute for Physiological Sciences, Myodaiji, Okazaki 444-8585, Japan, and ${ }^{3}$ Departamento \\ de Ciencias Biologicas, Laboratorio de Fisiologia y Biologia, Molecular, Facultad de Ciencias Exactas y Naturales, \\ Universidad de Buenos Aires, Buenos Aires 1428, Argentina
}

\begin{abstract}
Multiple types of high-voltage-activated $\mathrm{Ca}^{2+}$ channels trigger neurotransmitter release at the mammalian central synapse. Among them, the $\omega$-conotoxin GVIA-sensitive $\mathrm{N}$-type channels and the $\omega$-Aga-IVA-sensitive P/Q-type channels mediate fast synaptic transmission. However, at most central synapses, it is not known whether the contributions of different $\mathrm{Ca}^{2+}$ channel types to synaptic transmission remain stable throughout postnatal development. We have addressed this question by testing type-specific $\mathrm{Ca}^{2+}$ channel blockers at developing central synapses. Our results indicate that $\mathrm{N}$-type channels contribute to thalamic and cerebellar IPSCs only transiently during early postnatal period and P/Q-type channels predominantly mediate mature synaptic transmission, as we reported previously at the brainstem auditory synapse formed by the calyx of Held. In
\end{abstract}

Neurotransmitter release is triggered by $\mathrm{Ca}^{2+}$ entry through presynaptic voltage-dependent $\mathrm{Ca}^{2+}$ channels (Katz, 1969). In the mammalian CNS, fast synaptic transmission is mediated synergistically by multiple types of high-voltage-activated $\mathrm{Ca}^{2+}$ channels, including N-type, $\mathrm{P} / \mathrm{Q}$-type, and R-type $\mathrm{Ca}^{2+}$ channels (Luebke et al., 1993; Takahashi and Momiyama, 1993; Regehr and Mintz, 1994; Umemiya and Berger, 1994; Wheeler et al., 1994; Wu et al., 1998). Recently, however, the contribution of $\mathrm{N}$-type $\mathrm{Ca}^{2+}$ channels to rat auditory brainstem synaptic transmission was found to be restricted to the early postnatal period (Iwasaki and Takahashi, 1998). A similar transient contribution of $\mathrm{N}$-type channels to neuromuscular transmission was found in neonatal rats (Rosato Siri and Uchitel, 1999). These findings raise the possibility that the contribution of $\mathrm{N}$-type $\mathrm{Ca}^{2+}$ channels to synaptic transmission might be developmentally regulated at other CNS synapses. We have examined this possibility at cerebellar, thalamic, cerebral, and spinal cord synapses in rats of various postnatal ages. Although it is clear that $\mathrm{N}$-type $\mathrm{Ca}^{2+}$ channels contribute to synaptic transmission at many developing synapses, our results suggest that, at a subset of CNS synapses, there is a developmental switch to $\mathrm{P} / \mathrm{Q}-$ type $\mathrm{Ca}^{2+}$ channels.

\footnotetext{
Received Aug. 23, 1999; revised Oct. 7, 1999; accepted Oct. 8, 1999.

This work was supported by the Research for the Future Program by The Japan Society for the Promotion of Sciences to T.T. and PRESTO from Japan Science and Technology Corporation to A.M. We thank Mark Farrant and Toshiya Manabe for discussion and comments on this manuscript. We also thank Megumu Yoshimura for advice in spinal cord preparation.

Correspondence should be addressed to Tomoyuki Takahashi, Department of Neurophysiology, University of Tokyo Faculty of Medicine, Tokyo 113-0033, Japan. E-mail: ttakahas-tky@umin.u-tokyo.ac.jp.

Copyright (C) 1999 Society for Neuroscience $\quad 0270-6474 / 99 / 200059-07 \$ 15.00 / 0$
}

fact, $\mathrm{Ca}^{2+}$ currents directly recorded from the auditory calyceal presynaptic terminal were identified as N-, P/Q-, and R-types at postnatal day 7 (P7) to P10 but became predominantly P/Qtype at P13. In contrast to thalamic and cerebellar IPSCs and brainstem auditory EPSCs, N-type $\mathrm{Ca}^{2+}$ channels persistently contribute to cerebral cortical EPSCs and spinal IPSCs throughout postnatal months. Thus, in adult animals, synaptic transmission is predominantly mediated by $\mathrm{P} / \mathrm{Q}$-type channels at a subset of synapses and mediated synergistically by multiple types of $\mathrm{Ca}^{2+}$ channels at other synapses.

Key words: N-type calcium channels; P/Q-type calcium channels; postnatal development; transmitter release; central synapse; slice

\section{MATERIALS AND METHODS}

Preparation and solutions. Sagittal slices of cerebellum and thalamus, coronal slices of occipital neocortex, and transverse slices of brainstem (150- to $200-\mu \mathrm{m}$-thick) were prepared from 5- to 40-d-old Wistar rats killed by decapitation under halothane anesthesia. Transverse slices (250- $\mu \mathrm{m}$-thick) were prepared from lumbar spinal cord of 21- to 54-d-old Wistar rats dissected after laminectomy under urethane anesthesia (2.4 $\mathrm{gm} / \mathrm{kg}$, i.p.). Each slice was perfused with artificial CSF (aCSF) containing (in mM): $125 \mathrm{NaCl}, 2.5 \mathrm{KCl}, 26 \mathrm{NaHCO}_{3}, 10$ glucose, $1.25 \mathrm{NaH}_{2} \mathrm{PO}_{4}$, $2 \mathrm{CaCl}_{2}$, and $1 \mathrm{MgCl}_{2}, \mathrm{pH} 7.4$, with $95 \% \mathrm{O}_{2}$ and $5 \% \mathrm{CO}_{2}$. Neurons in slices were visually identified with a 40 or $60 \times$ water immersion objective attached to an upright microscope (Axioskop, Zeiss, Oberkochen, Germany; or BX50WI, Olympus Opticals, Tokyo, Japan). For recording IPSCs, patch pipettes were filled with an internal solution containing 140 mм CsCl, 9 mм NaCl, 1 mм EGTA, 10 mм HEPES, and 2 mм MgATP, pH 7.3 adjusted with $\mathrm{CsOH}$, and 6-cyano-7-nitroquinoxaline-2,3-dione (CNQX) (10 $\mu \mathrm{M}$; Tocris Cookson, Bristol, UK) was added to the aCSF. To isolate GABAergic IPSCs from glycinergic IPSCs, strychnine $(0.5$ $\mu \mathrm{M}$; Sigma, St. Louis, MO) was added to the aCSF. To isolate glycinergic IPSCs from GABAergic IPSCs, bicuculline (10 $\mu \mathrm{M}$; Sigma) was added to the aCSF. For recording EPSCs, pipettes were filled with an internal solution containing $35 \mathrm{~mm} \mathrm{CsF}, 100 \mathrm{~mm} \mathrm{CsCl}, 1 \mathrm{~mm} \mathrm{MgCl}_{2}, 10 \mathrm{~mm}$ EGTA, and $10 \mathrm{~mm}$ HEPES, pH 7.3 adjusted with $\mathrm{CsOH}$, and bicuculline $(10 \mu \mathrm{M})$ and strychnine $(0.5 \mu \mathrm{M})$ were added to the aCSF. To isolate non-NMDA-EPSCs, D-2-amino-5-phosphonopentanoic acid (D-AP-5) (Tocris Cookson) was included in the aCSF. For recording calcium currents from the calyx of Held, tetraethylammonium chloride (TEA-Cl) (10 mM; Nakarai, Kyoto, Japan) and tetrodotoxin (TTX) (1 $\mu \mathrm{M}$; Wako, Osaka, Japan) were added to the aCSF. The presynaptic patch pipettes were filled with (in mM): $110 \mathrm{CsCl}, 40$ HEPES, 0.5 EGTA, $1 \mathrm{MgCl}_{2}, 12$ $\mathrm{Na}_{2}$ phosphocreatine, 10 TEA-Cl, 2 ATP-Mg, and 0.5 GTP.

Recording, drug application, and data analysis. Whole-cell voltageclamp recordings of synaptic currents were made from visually identified neurons at the holding potential of $-70 \mathrm{mV}$ (unless otherwise noted) using a patch-clamp amplifier (Axopatch 200B). Postsynaptic and presynaptic electrodes had resistances of 2-4 and 5-7 M $\Omega$, respectively. The 


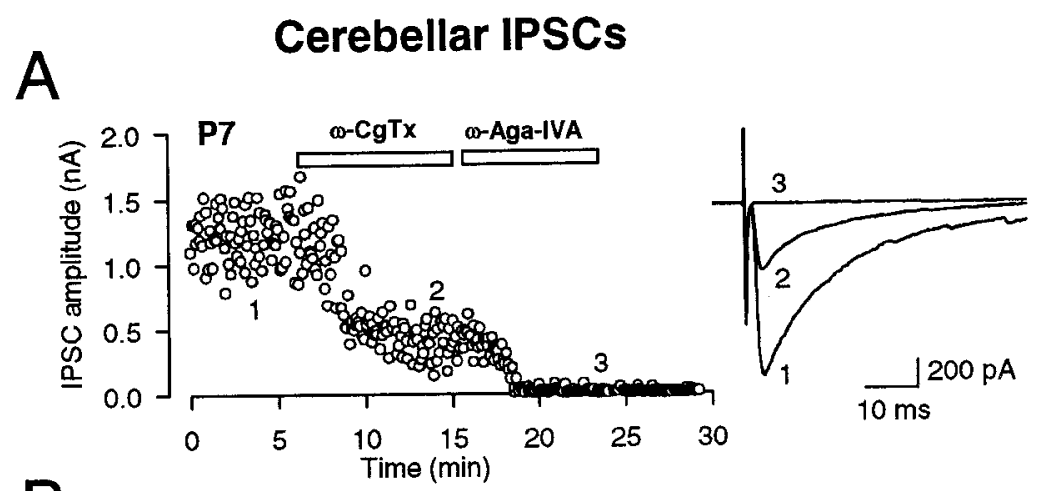

Figure 1. Developmental decline in the $\omega$-CgTx sensitivity of GABAergic IPSCs in deep cerebellar nuclear cells. IPSCs were recorded in the presence of CNQX $(10 \mu \mathrm{M})$ and strychnine $(0.5 \mu \mathrm{M})$ and were blocked by bicuculline $(10$ $\mu \mathrm{M}$; data not shown). $A$, At P7, $\omega-\mathrm{CgTx}(3 \mu \mathrm{M})$ reduced the amplitude of IPSCs by $68 \%$. Subsequent application of $\omega$-Aga-IVA (200 nM) blocked the remaining IPSCs. $B$, At P16, $\omega$-CgTx no longer affected IPSCs, whereas $\omega$-AgaIVA blocked IPSCs. Superimposed sample records $(A, B)$ are averages of 10 consecutive IPSCs at a holding potential of $-70 \mathrm{mV}$ before $\omega$-CgTx application (1), after $\omega$-CgTx application (2), and after $\omega$-Aga-IVA application (3). In this and following figures (Figs. 2, 4), each data point represents the amplitude of an individual synaptic current. $C$, The fraction of IPSCs blocked by $\omega$-CgTx application at different postnatal days. Symbols and error bars are mean \pm SEMs amplitudes derived from five to eight cells at each age.
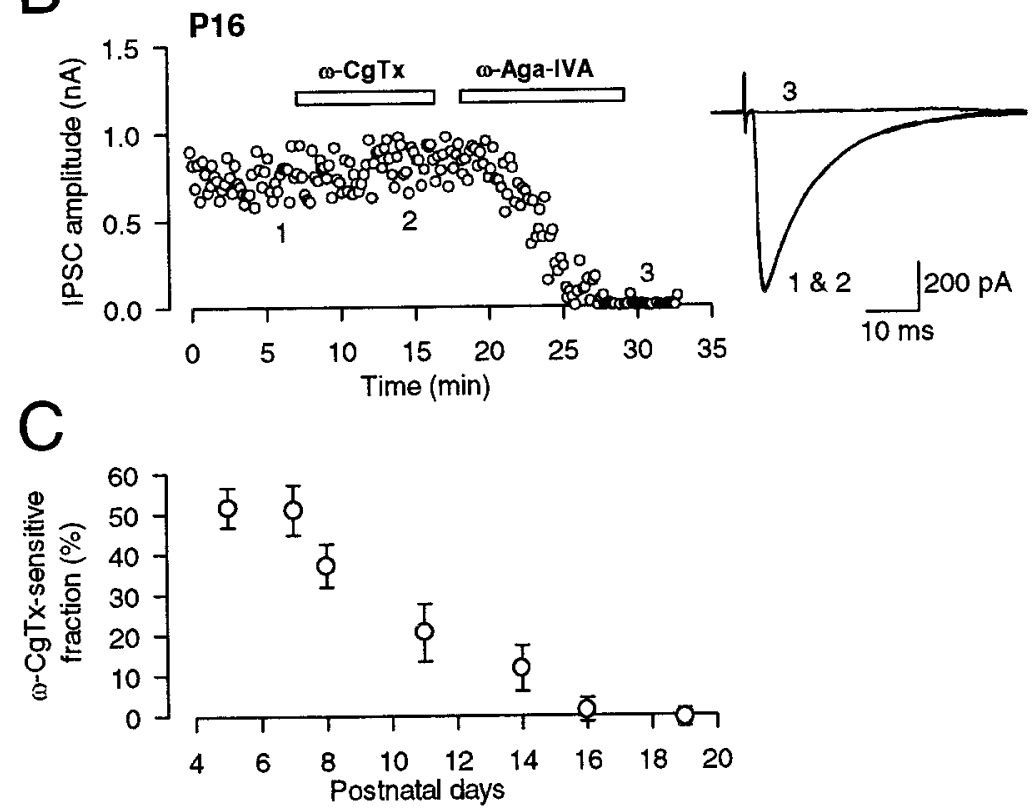

access resistance for postsynaptic recording was 6-12 $\mathrm{M} \Omega$. The access resistance for presynaptic recording was $12-20 \mathrm{M} \Omega$ and compensated by $70 \%$. Stimulation of synaptic input was made with a glass pipette filled with $1 \mathrm{M} \mathrm{NaCl}$. The pipette was positioned in the vicinity of Purkinje cell axons to evoke GABAergic IPSCs in deep cerebellar nuclear cells (Takahashi and Momiyama, 1993), in the reticular nucleus thalami (RNT) to evoke GABAergic IPSCs in thalamic relay cells, in the vicinity of neighboring interneurons to evoke glycinergic IPSCs in spinal dorsal horn neurons, and in the layer VI border of the white matter to evoke non-NMDA-EPSCs in layer IV pyramidal cells in visual cortex. Synaptic currents were evoked at $0.1-0.2 \mathrm{~Hz}$. Presynaptic $\mathrm{Ca}^{2+}$ currents were evoked by a $10 \mathrm{msec}$ depolarizing pulse from $-80 \mathrm{mV}$ holding potential to $-10 \mathrm{mV}$ under voltage clamp at $0.1 \mathrm{~Hz}$. Synthetic $\omega$-Aga-IVA $(200 \mathrm{~nm}$; Peptide Institute, Osaka, Japan) and $\omega$-conotoxin GVIA ( $\omega$-CgTx) (3 $\mu \mathrm{M}$; Peptide Institute) were dissolved in oxygenated aCSF containing cytochrome c (1 mg/ml; Sigma) just before bath application. Records were low-pass filtered at $2-5 \mathrm{kHz}$ and digitized at $10 \mathrm{kHz}$ by a LM-12 interface (Dagan Instruments, Minneapolis, MN) or Digidata 1200 (Axon Instruments, Foster City, CA). Leak subtraction of $\mathrm{Ca}^{2+}$ currents was made by a P/N protocol (Takahashi et al., 1998). Values in the text and figures are given as means \pm SEMs, and unless otherwise stated, differences between groups were evaluated by Steel's multiple comparison test, with $p<0.05$ taken as the level of significance. All experiments were performed at room temperature $\left(23-27^{\circ} \mathrm{C}\right)$.

\section{RESULTS}

\section{Developmental decline of $\omega$-conotoxin-sensitivity in GABAergic IPSCs}

IPSCs were evoked in deep cerebellar nuclear cells by stimulating putative Purkinje cell axons extracellularly in the presence of
CNQX $(10 \mu \mathrm{M})$ and strychnine $(0.5 \mu \mathrm{M})$. The IPSCs were blocked by bicuculline $(10 \mu \mathrm{M})$, indicating that they are mediated by $\mathrm{GABA}_{\mathrm{A}}$ receptors (data not shown). At postnatal day 7 (P7), the N-type $\mathrm{Ca}^{2+}$ channel blocker $\omega$-CgTx at a saturating concentration $(3 \mu \mathrm{M})$ partially and irreversibly (data not shown) blocked the amplitude of IPSCs (Fig. $1 A$ ). The remaining fraction of IPSCs after $\omega$-CgTx application $(49.1 \pm 6.2 \% ; n=5)$ was almost completely abolished by the P/Q-type $\mathrm{Ca}^{2+}$ channel blocker $\omega$-Aga-IVA (200 nM). These results confirm our previous report (Takahashi and Momiyama, 1993), indicating that multiple $\mathrm{Ca}^{2+}$ channels are involved in synaptic transmission at this synapse at P6-P8. However, in older animals, the blocking effect of $\omega$-CgTx became progressively less (Fig. $1 C$ ) until it was eventually lost at P16 (Fig. $1 B$ ), with the $\omega$-CgTx-sensitive fraction being $<2 \%(n=5)$ (Fig. $1 C)$. In contrast, $\omega$-Aga-IVA nearly abolished IPSCs in rats older than P16 (Fig. 1B), suggesting that GABAergic inhibitory transmission from Purkinje cells to deep nuclear cells is exclusively mediated by the $\mathrm{P} / \mathrm{Q}$-type $\mathrm{Ca}^{2+}$ channels in mature animals.

GABAergic neurons in RNT provide a major inhibitory innervation onto thalamic relay cells, thereby contributing to thalamocortical rhythm generation (Steriade and Llinas, 1988). Bicuculline-sensitive GABAergic IPSCs were evoked in thalamocortical relay neurons in the laterodorsal (LD) thalamic nucleus by stimulating the RNT in the presence of CNQX $(10 \mu \mathrm{M})$, 


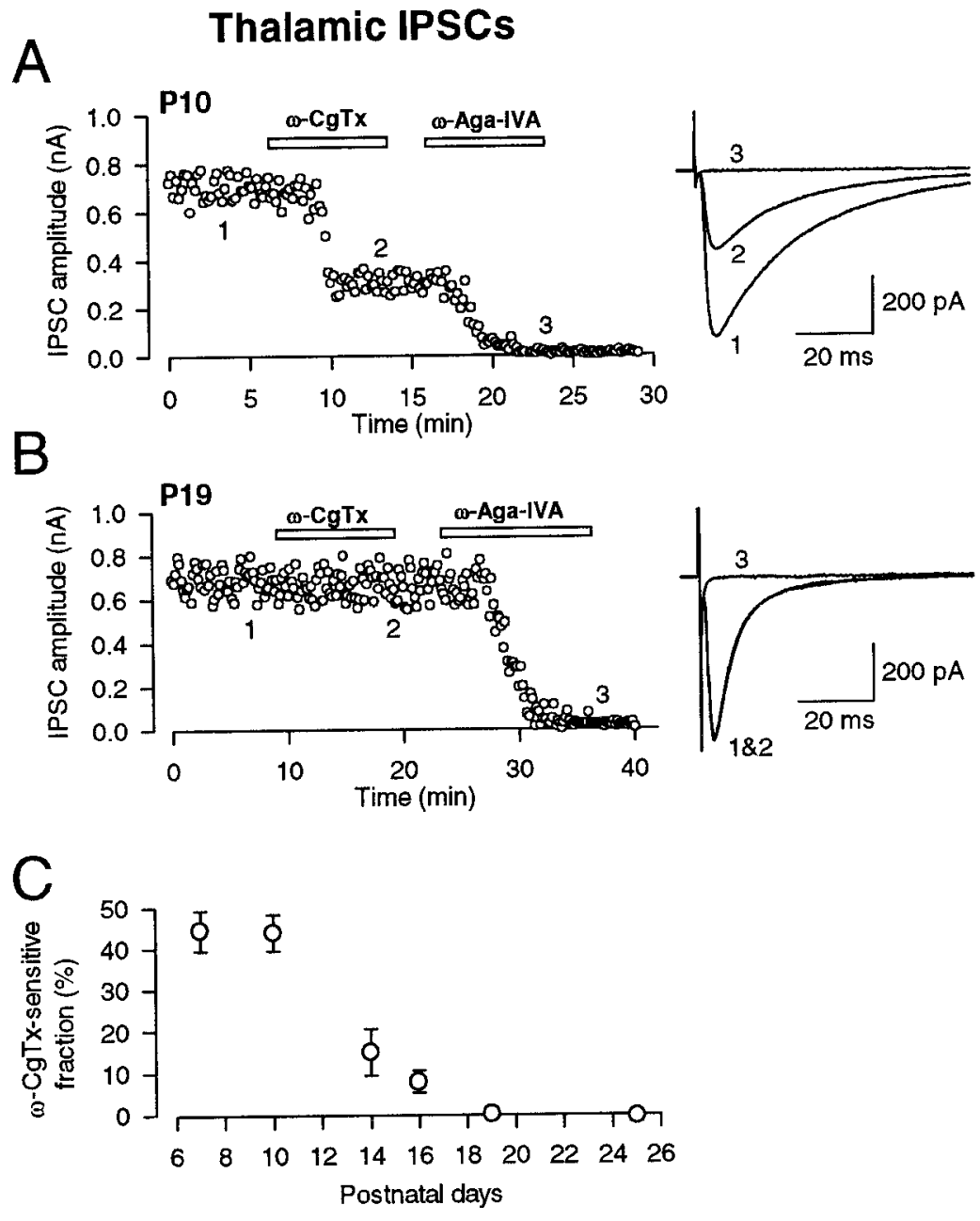

\begin{abstract}
Figure 2. Developmental decline in the $\omega$-CgTx sensitivity of GABAergic IPSCs in the LD thalamic nucleus. IPSCs were recorded in the presence of CNQX $(10 \mu \mathrm{M})$, D-AP-5 $(50 \mu \mathrm{M})$, and strychnine $(0.5 \mu \mathrm{M})$ and could be blocked by bicuculline (10 $\mu \mathrm{M}$; data not shown). $A$, At $\mathrm{P} 10, \omega$-CgTx (3 $\mu \mathrm{M})$ reduced the amplitude of IPSCs by $53 \%$. Subsequent application of $\omega$-Aga-IVA (200 nM) blocked the remaining IPSCs. Sample records of 10 IPSCs before $\omega$-CgTx application (1), after $\omega$-CgTx application (2), and after $\omega$-AgaIVA application (3) were averaged and superimposed $(A$, $B)$. The holding potential was $-70 \mathrm{mV}$. $B$, At P19, $\omega$-CgTx no longer affected IPSCs, whereas $\omega$-Aga-IVA almost completely blocked IPSCs. $C$, The fraction of IPSCs blocked by $\omega$-CgTx application at different postnatal ages. Symbols and error bars as above $(n=5-6)$.
\end{abstract}

strychnine $(0.5 \mu \mathrm{M})$, and D-AP-5 $(50 \mu \mathrm{M})$. At P7-P10, $\omega$-CgTx attenuated thalamic IPSCs (Fig. $2 A)$ by $55.8 \pm 3.1 \%(n=11)$ (Fig. $2 C$ ). The fraction remaining after $\omega$-CgTx application was abolished by $\omega$-Aga-IVA (Fig. $2 A$ ). Similar to cerebellar IPSCs, the $\omega$-CgTx-sensitive fraction decreased as animals matured (Fig. $2 C)$. At P19, IPSCs were no longer attenuated by $\omega$-CgTx but were completely abolished by $\omega$-Aga-IVA (Fig. $2 B$ ). These results, and those at the brainstem auditory EPSCs (Iwasaki and Takahashi, 1998), suggest that an N-type to-P/Q-type switch of presynaptic $\mathrm{Ca}^{2+}$ channel type may be common among many central synapses.

If transmitter release increases with development, postsynaptic receptors may become saturated by transmitters. Also, as reported at the calyx of Held (Chuhma and Ohmori, 1998), the relationship between $\mathrm{Ca}^{2+}$ influx and transmitter release may shift developmentally and become saturated with $\mathrm{Ca}^{2+}$ influx in normal external $\left[\mathrm{Ca}^{2+}\right]$. These might cause an apparent decline of $\omega$-CgTx sensitivity. To exclude these possibilities, we have reduced IPSCs by reducing external $\left[\mathrm{Ca}^{2+}\right]$ to $1 \mathrm{~mm}$ and increasing $\left[\mathrm{Mg}^{2+}\right]$ to $2 \mathrm{~mm}$. Although this treatment reduced cerebellar and thalamic IPSCs down to $31.2 \pm 2.2 \%(n=5)$ and $26.2 \pm$ $2.9 \%(n=5)$, respectively, $\omega$-CgTx still had no effect on IPSCs (99.1 $\pm 1.7 \%$ remaining at P17 cerebellum; $102.9 \pm 2.9 \%$ at P20 thalamus; $n=5$ each). During postnatal development, thalamic IPSCs showed a clear kinetic speeding at the decay time, possibly because of the developmental switch of $\mathrm{GABA}_{\mathrm{A}}$ receptor $\alpha$ subunits (Onodera and Takahashi, 1996). No such kinetic change was observed for the GABAergic IPSCs between cerebellar Purkinje cell and deep cerebellar nuclear cell (Fig. 1), as reported for the basket/stellate cell-Purkinje cell IPSCs (Pouzat and Hestrin, 1997).

\section{Developmental elimination of multiple calcium channel types at the calyx of Held}

Developmental decline of $\omega$-CgTx sensitivity in synaptic currents may be caused by the disappearance of $\mathrm{N}$-type $\mathrm{Ca}^{2+}$ channels from presynaptic terminals or a decoupling of presynaptic $\mathrm{Ca}^{2+}$ channels from the exocytotic machinery. To determine which of these changes takes place, we recorded $\mathrm{Ca}^{2+}$ currents directly from the giant presynaptic terminal, the calyx of Held, in the brainstem slices (Borst et al., 1995; Takahashi et al., 1996, 1998; Forsythe et al., 1998; Wu et al., 1998). At P7, $\mathrm{Ca}^{2+}$ currents were partially blocked by $\omega$-CgTx $(3 \mu \mathrm{M})$ and also by $\omega$-Aga-IVA (200 nM), with the magnitude of suppression being $28.4 \pm 2.4$ and $55.3 \pm 2.4 \%$, respectively $(n=5)$ (Fig. $3 A$ ). The substantial fraction $(16.4 \pm 2.8 \% ; n=5)$ remaining after application of both toxins was completely blocked by $\mathrm{Cd}^{2+}$. These results confirm those reported by Wu et al. (1998, 1999), suggesting that N-, P/Q-, and R-type channels coexist at the presynaptic terminal and contribute to synaptic transmission at this age. At P10, all three types of $\mathrm{Ca}^{2+}$ channels were still present at the presynaptic 
Figure 3. Developmental decline of $\mathrm{N}$ - and R-type $\mathrm{Ca}^{2+}$ channels in the giant presynaptic terminal, the calyx of Held. Presynaptic $\mathrm{Ca}^{2+}$ currents $\left(I p_{\mathrm{Ca}}\right)$ were evoked by a $10 \mathrm{msec}$ depolarizing pulse from $-80 \mathrm{mV}$ holding potential to $-10 \mathrm{mV}$ under voltage clamp every $10 \mathrm{sec}$ in the presence of TTX $(0.1 \mu \mathrm{M})$ and TEA-Cl $(10 \mathrm{~mm})$. A, At P7, $\omega$-CgTx $(3 \mu \mathrm{M})$ reduced the amplitude of $I p_{\mathrm{Ca}}$ by $23 \%(2)$, whereas $\omega$-Aga-IVA (200 nM) by $66 \%$ (3). The fraction remaining after application of both toxins $(11 \%)$ was abolished by $\mathrm{Cd}^{2+}(100 \mu \mathrm{M} ; 4)$. B. At P13, $\omega$-CgTx had no effect on $I p_{\mathrm{Ca}}$, whereas $\omega$-Aga-IVA almost completely abolished $I p_{\mathrm{Ca}}$ (3) with no appreciable remaining $\mathrm{Cd}^{2+}$. sensitive component (4). $C$, The fraction of $I p_{\mathrm{Ca}}$ blocked by $\omega$-CgTx $(N, \bigcirc), \omega$-Aga-IVA $(P / Q, \square)$, and that insensitive to the toxins but blocked by $\mathrm{Cd}^{2+}(R, \triangle)$ at three different postnatal ages. Symbols and error bars derived from five to eight cells at each age.

terminal, but $\mathrm{N}$-type channels were significantly reduced, and $\mathrm{P} / \mathrm{Q}$ type channels increased (Fig. 3C). At P13, $\omega$-CgTx no longer affected presynaptic $\mathrm{Ca}^{2+}$ currents, whereas $\omega$-Aga-IVA completely abolished them (Fig. 3B) (Takahashi et al., 1996). After application of $\omega$-Aga-IVA, little $\mathrm{Cd}^{2+}$-sensitive component remained. These results suggest that $\mathrm{N}$-type and $\mathrm{R}$-type $\mathrm{Ca}^{2+}$ channels are lost from the calyceal presynaptic terminals, being replaced by $\mathrm{P} / \mathrm{Q}$ type $\mathrm{Ca}^{2+}$ channels during postnatal development.

\section{Persistent $\omega$-CgTx sensitivity of cerebral cortical EPSCs and spinal cord IPSCs through postnatal development}

Although developmental loss in the contribution of N-type $\mathrm{Ca}^{2+}$ channels was observed at various central synapses, this was found not to be a general rule. Non-NMDA-EPSCs were evoked in layer IV pyramidal cells of visual cortical slices by stimulating at the borders between the white matter and layer VI in the presence of D-AP-5 $(50 \mu \mathrm{M})$, strychnine $(0.5 \mu \mathrm{M})$, and bicuculline (10 $\mu \mathrm{M})$. These EPSCs are likely to derive from excitatory afferents containing geniculo-cortical projections, which represent the main component of the excitatory input to layer IV neurons from subcortical structures, as well as from cortical connections (Katz and Callaway, 1992; Carmignoto and Vicini, 1992). At P40, non-NMDA-EPSCs had fast kinetics in rise and decay times relative to those at $\mathrm{P} 10$ (Fig. 4), suggesting that transmitter release may become more synchronous with development at this
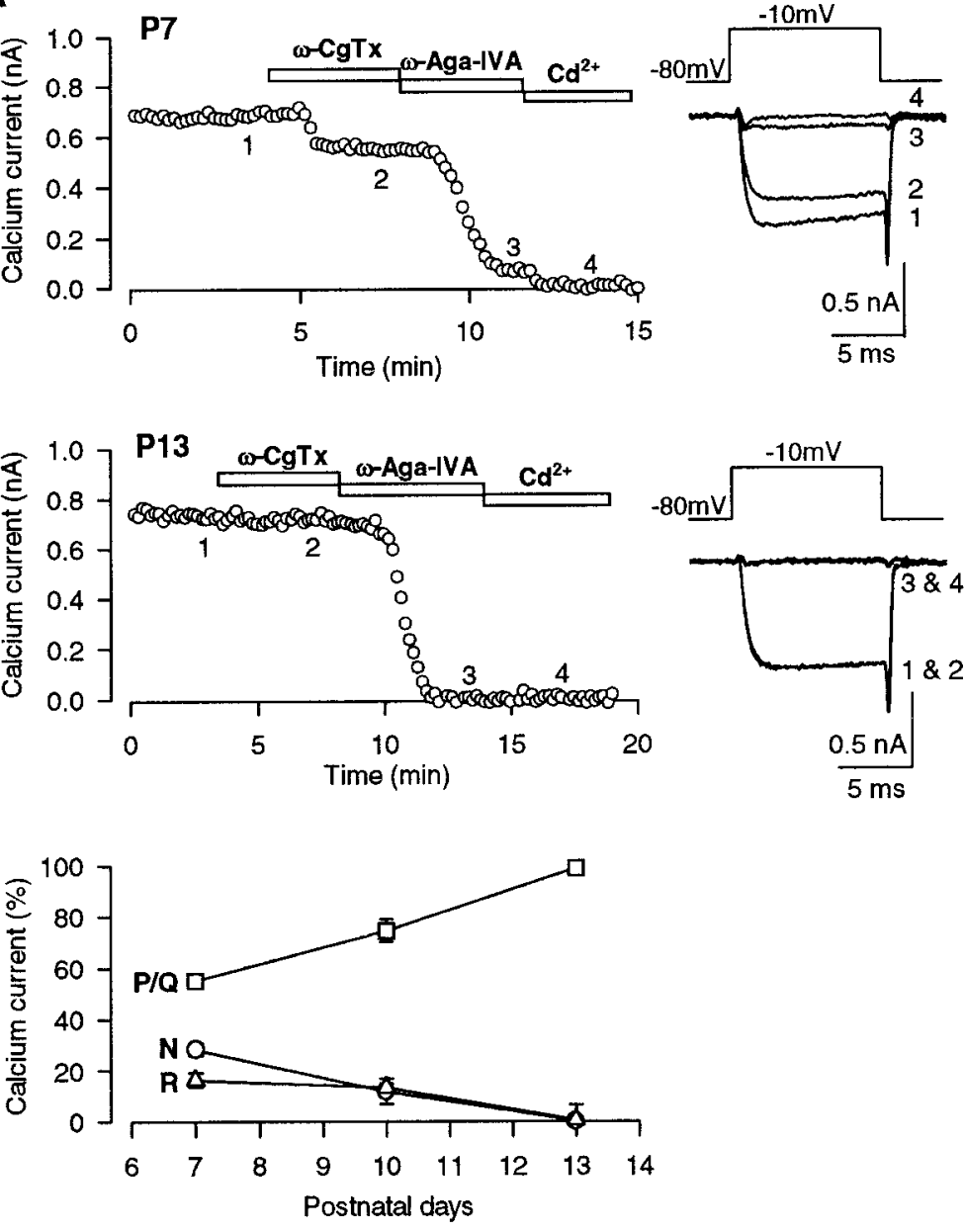

synapse. However, we observed no change in the relative contribution of different $\mathrm{Ca}^{2+}$ channel types over this period. At $\mathrm{P} 10$, $\omega$-CgTx blocked non-NMDA-EPSCs (Fig. $4 A$ ) by $42.0 \pm 4.8 \%$ $(n=6)$. The blocking effect of $\omega$-CgTx remained similar, at least until P40 (Fig. 4B). The remaining fraction of EPSCs after $\omega$-CgTx was almost completely blocked by $\omega$-Aga-IVA. These results suggest that both $\mathrm{N}$-type and $\mathrm{P} / \mathrm{Q}$-type $\mathrm{Ca}^{2+}$ channels contribute to synaptic transmission throughout the postnatal developmental period at this synapse.

Another example of persistent $\omega$-CgTx sensitivity during development was observed for glycinergic IPSCs in dorsal horn neurons of the spinal cord, evoked by stimulating neighboring interneurons. These IPSCs evoked in the presence of CNQX (10 $\mu \mathrm{M})$, bicuculline $(10 \mu \mathrm{M})$ and D-AP-5 $(25 \mu \mathrm{M})$ were blocked by strychnine $(0.5 \mu \mathrm{M}$; data not shown $)$, suggesting that they were mediated by glycine receptors. At P21-P27, $\omega$-CgTx $(3 \mu \mathrm{M})$ blocked glycinergic IPSCs (Fig. $5 B)$ by $49.9 \pm 7.1 \%(n=7)$, which is similar in magnitude to that reported previously for these synapses at P4-P8 (51 \pm 9\%) (Takahashi and Momiyama, 1993). At P44-P54, $\omega$-CgTx similarly blocked glycinergic IPSCs (by $36.9 \pm 8.9 \% ; n=8$; not significantly different from $\mathrm{P} 4-\mathrm{P} 8$ or P21-P27) (Fig. 5A,B). At all ages, $\omega$-Aga-IVA abolished EPSCs remaining after the $\omega$-CgTx application (Fig. 5A). Thus, these results are similar to those for cerebral cortical EPSCs but clearly contrast with those for cerebellar and thalamic IPSCs and brainstem auditory EPSCs (Iwasaki and Takahashi, 1998). 


\section{Cerebral Cortical EPSCs}

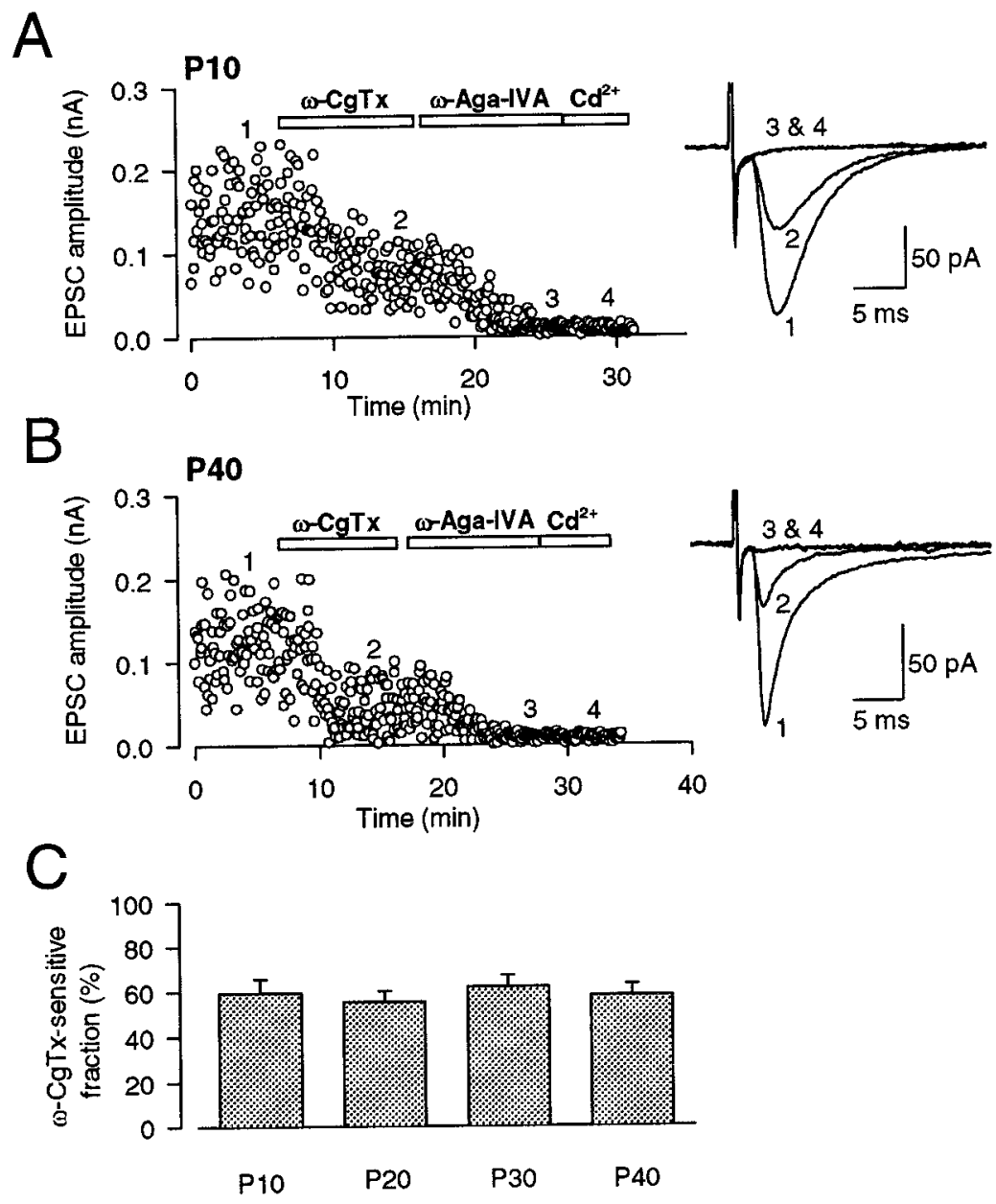

Figure 4. Persistent $\omega$-CgTx sensitivity of non-NMDAEPSCs in pyramidal neurons of visual cortex. EPSCs were recorded in the presence of D-AP-5 $(50 \mu \mathrm{M})$, bicuculline $(20$ $\mu \mathrm{M})$, and strychnine $(0.5 \mu \mathrm{M})$ and blocked by CNQX (10 $\mu \mathrm{M}$; data not shown). $A$, At $\mathrm{P} 10, \omega-\mathrm{CgTx}(3 \mu \mathrm{M})$ reduced the amplitude of EPSCs by $43 \%$. Subsequent application of $\omega$-Aga-IVA (200 nM) almost completely blocked the remaining EPSCs. $B$, At $\mathrm{P} 40, \omega-\mathrm{CgTx}$ reduced the amplitude of EPSCs by $64 \%$ in this cell, and subsequent application of $\omega$-Aga-IVA (200 nM) almost completely blocked the remaining EPSCs. Sample records of 20 EPSCs before $\omega$-CgTx application (1), after $\omega$-CgTx application (2), after $\omega$-Aga-IVA application (3), and after $\mathrm{Cd}^{2+}$ application (4) were averaged and superimposed $(A, B)$. The holding potential was $-70 \mathrm{mV}$. $C$, The $\omega$-CgTx-sensitive fraction at different postnatal ages. The mean \pm SEMs derived from five to six cells are shown in bar graphs.

\section{DISCUSSION}

Using type-specific $\mathrm{Ca}^{2+}$ channel blocker toxins, we have demonstrated that the contributions of $\mathrm{N}$-type $\mathrm{Ca}^{2+}$ channels to cerebellar and thalamic inhibitory synaptic transmission are lost during postnatal development. These results are consistent with those at the rat auditory brainstem excitatory synapse (Iwasaki and Takahashi, 1998) and neuromuscular junction (Rosato Siri and Uchitel, 1999), suggesting that $\mathrm{Ca}^{2+}$ channels involved in transmitter release switch developmentally from N-type to P/Qtype at various mammalian fast synapses. Direct recordings of presynaptic $\mathrm{Ca}^{2+}$ currents from the auditory brainstem presynaptic terminals indicated that both $\mathrm{N}$-type and $\mathrm{R}$-type $\mathrm{Ca}^{2+}$ channels disappear with postnatal development. As illustrated in Figure 6, the disappearance of N-type $\mathrm{Ca}^{2+}$ channels at the cerebellar and thalamic inhibitory synapses occurred several days later than those at the brainstem auditory synapse (Iwasaki and Takahashi, 1998) or neuromuscular junction (Rosato Siri and Uchitel, 1999).

What is the mechanism underlying the developmental switch of $\mathrm{Ca}^{2+}$ channel types? One possibility would be the type-specific regulation of de novo synthesis of $\mathrm{Ca}^{2+}$ channels during development. Another possibility would be the $\mathrm{Ca}^{2+}$ channel typespecific sorting, which is developmentally regulated. Within a given type of neuron, $\mathrm{Ca}^{2+}$ channel subtypes are differentially sorted between soma and neurites (Christie et al., 1995; Mouginot et al., 1997; Doughty et al., 1998; Plant et al., 1998). In fact, at the early postnatal period, $\mathrm{N}$-type $\mathrm{Ca}^{2+}$ channels are involved in synaptic transmission at the nerve terminal of cerebellar Purkinje cells (Takahashi and Momiyama, 1993), whereas these channels are not expressed at the soma (Mintz et al., 1992). Similarly, in facial motoneurons of neonatal rats, $\mathrm{P} / \mathrm{Q}$-type $\mathrm{Ca}^{2+}$ channels are involved in synaptic transmission (M. D. Rosato Siri and O. D. Uchitel, unpublished observation) but not expressed in the soma (Plant et al., 1998). At the nerve terminals of anteroventral cochlear neurons, the calyx of Held, we have shown that $\mathrm{N}$ - and R-type $\mathrm{Ca}^{2+}$ channels are replaced by $\mathrm{P} / \mathrm{Q}$-type $\mathrm{Ca}^{2+}$ channels with development. In contrast, multiple types of $\mathrm{Ca}^{2+}$ channels at the soma of these neurons do not exhibit developmental changes (Doughty et al., 1998). All of these results suggest that channel type-specific sorting mechanisms rather than the regulation of $d e$ novo synthesis may underlie the developmental switch of presynaptic $\mathrm{Ca}^{2+}$ channels.

What is the functional outcome of the N-type to-P/Q-type $\mathrm{Ca}^{2+}$ channel switch? At the calyx of Held of immature animals, for example, $\mathrm{Ca}^{2+}$ channel subtypes are located differentially, with $\mathrm{N}$ - and $\mathrm{R}$-type $\mathrm{Ca}^{2+}$ channels being more distant from release site than $\mathrm{P} / \mathrm{Q}$-type $\mathrm{Ca}^{2+}$ channels (Wu et al., 1999). Our previous (Iwasaki and Takahashi, 1998) and present results indicate that these remote $\mathrm{Ca}^{2+}$ channels disappear with postnatal development. This will change the spatiotemporal profile of presynaptic $\mathrm{Ca}^{2+}$ channel domain (Augustine et al., 1991) toward more synchronous transmitter release (Chuhma and Ohmori, 
Figure 5. Persistent $\omega$-CgTx sensitivity in glycinergic IPSCs in dorsal horn neurons of spinal cord. IPSCs were recorded in the presence of CNQX $(10 \mu \mathrm{M}), \mathrm{D}-\mathrm{AP}-5(25$ $\mu \mathrm{M})$, and bicuculline $(20 \mu \mathrm{M})$ and were blocked by strychnine $(0.5 \mu \mathrm{M}$; data not shown). A, At P54, $\omega$-CgTx $(3 \mu \mathrm{M})$ reduced the amplitude of IPSCs by $28 \%$. Subsequent application of $\omega$-Aga-IVA (200 nM) blocked the remaining IPSCs. Each symbol represents the mean amplitude of 10 consecutive IPSCs. Sample records of 20 IPSCs before $\omega$-CgTx application (1), after $\omega$-CgTx application (2), and after $\omega$-Aga-IVA application (3) were averaged and superimposed. Holding potential was $-40 \mathrm{mV}$. B, The $\omega$-CgTxsensitive fraction at different postnatal periods. The mean \pm SEMs derived from seven to eight cells (holding potentials between -40 and $-70 \mathrm{mV}$ ) are shown in bar graphs. Data at P4-P8 are taken from Takahashi and Momiyama (1993). No significant difference between P21-P27 and P44-P54 $(p=0.281)$.

Figure 6. Age-dependent changes in the $\omega$-CgTx-sensitive fraction at different central synapses. Data for brainstem auditory EPSCs are taken from Iwasaki and Takahashi (1998). EPSCs and IPSCs are indicated by filled and open symbols, respectively. Brainstem (๑) and cerebral

EPSCs, and cerebellar $(\square)$, thalamic $(\bigcirc)$, and spinal $(\triangle)$

IPSCs. Symbols and error bars indicate mean \pm SEMs.

1998). It has been reported that the G-protein-coupled receptors, such as adenosine receptors (Mogul et al., 1993; Umemiya and Berger, 1994) or metabotropic glutamate receptors (Stefani et al., 1998), are differentially linked to $\mathrm{N}$ - or P/Q-type $\mathrm{Ca}^{2+}$ channels in the presynaptic terminals. Such a differential linkage might also arise, at least in part, from differential localization of $\mathrm{Ca}^{2+}$ channel subtypes relative to the functional domain of G-proteincoupled receptors (Takahashi et al., 1998). In this respect, developmental redistribution of $\mathrm{Ca}^{2+}$ channels in combination with developmental changes in the presynaptic receptor expression (Baskys and Malenka, 1991; Elezgarai et al., 1999) may contribute to remodeling of presynaptic modulation.

In contrast to cerebellar and thalamic IPSCs and brainstem auditory EPSCs, cerebral cortical EPSCs and spinal cord dorsal horn IPSCs remained similarly sensitive to $\omega$-CgTx throughout

\section{Spinal dorsal horn IPSCs}
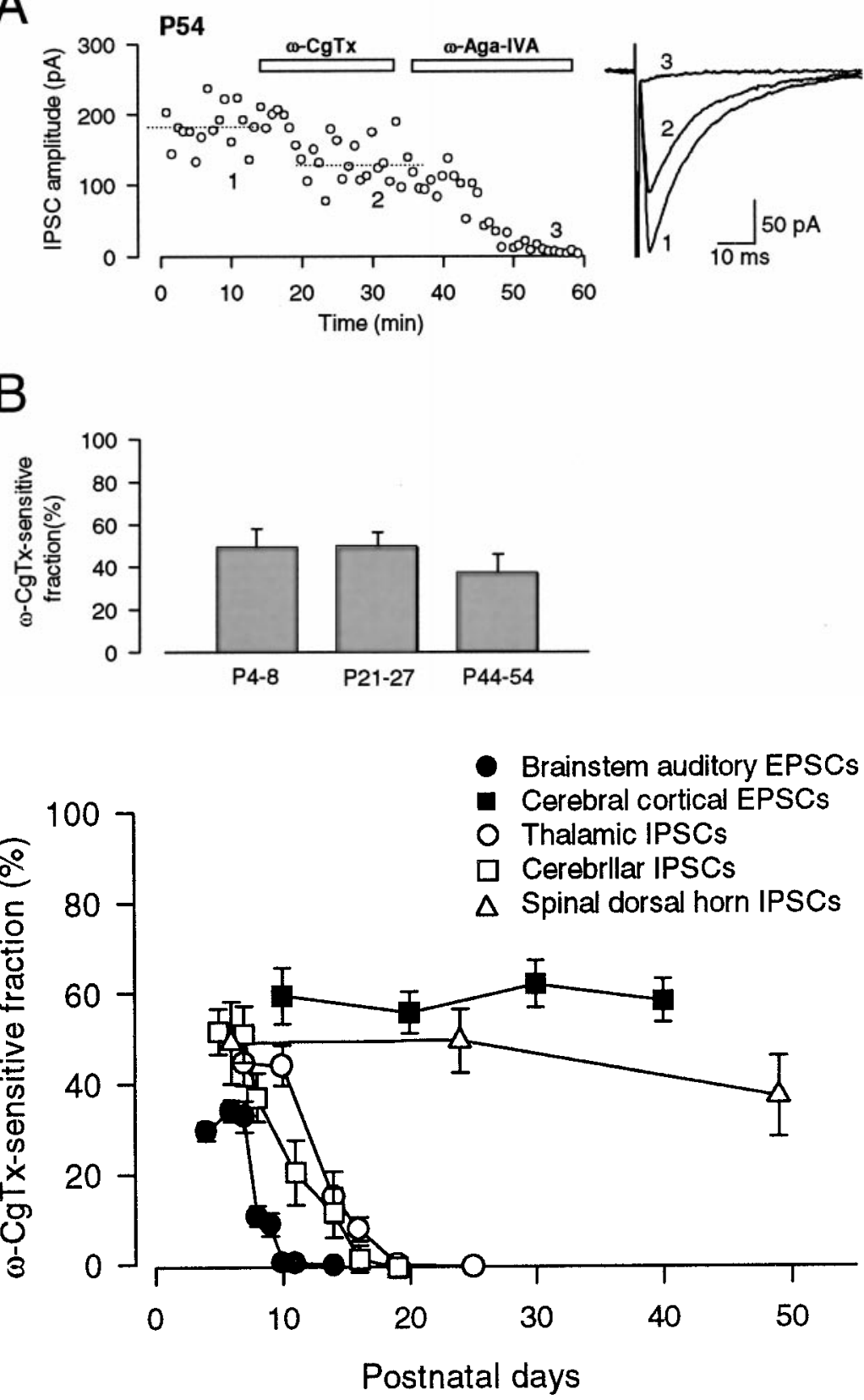

postnatal development (Fig. 6). In fact, N-type channel $\alpha_{1 \mathrm{~B}}$ subunit immunoreactivity has been detected at the nerve terminals of dorsal cerebral cortex (Westenbroek et al., 1992) and spinal cord (Westenbroek et al., 1998) of adult rats. In adult animals, hippocampal synaptic transmission is mediated in part by N-type $\mathrm{Ca}^{2+}$ channels (Luebke et al., 1993; Wheeler et al., 1994). However, in hippocampal neurons in culture, the relative contribution of N-type $\mathrm{Ca}^{2+}$ channels to synaptic transmission has been reported to decline with days in culture (Scholz and Miller, 1995). It is possible that a similar developmental decline of $\mathrm{N}$-type $\mathrm{Ca}^{2+}$ channels occurs at hippocampal synapses in situ as well.

Besides neurotransmission, $\mathrm{N}$-type $\mathrm{Ca}^{2+}$ channels are thought to be involved also in cell migration (Komuro and Rakic, 1993) and synaptogenesis (Vigers and Pfenninger 1991) during the early development. The contribution of N-type $\mathrm{Ca}^{2+}$ channels to syn- 
aptic transmission seems general among synapses in developing animals, but it remains only in a subset of synapses in mature animals. It has been reported that $\mathrm{N}$-type $\mathrm{Ca}^{2+}$ channels are specifically involved in nociceptive transmission (Chaplan et al., 1994; Omote et al., 1996; Westenbroek et al., 1998); therefore, $\omega$-CgTx can be a potential analgesic agent for chronic pain treatment (Miljanich and Ramachandran, 1995). Thus, it would be important to clarify what other functional roles bear N-type $\mathrm{Ca}^{2+}$ channels remaining at mature CNS synapses.

\section{REFERENCES}

Augustine GJ, Adler EM, Charlton MP (1991) The calcium signal for transmitter secretion from presynaptic nerve terminals. (Stanley EF, Nowicky MC, Triggle DJ, eds), pp 365-381. New York: New York Academy of Sciences.

Baskys A, Malenka RC (1991) Agonists at metabotropic glutamate receptors presynaptically inhibit EPSCs in neonatal rat hippocampus. J Physiol (Lond) 444:687-701.

Borst JGG, Helmchen F, Sakmann B (1995) Pre- and postsynaptic whole-cell recordings in the medial nucleus of the trapezoid body of the rat. J Physiol (Lond) 489:825-840.

Carmignoto G, Vicini S (1992) Activity-dependent decrease in NMDA receptor responses during development of the visual cortex. Science 258:1007-1011.

Chaplan SR, Pogrel JW, Yaksh TL (1994) Role of voltage-dependent calcium channel subtypes in experimental tactile allodynia. J Pharmacol Exp Ther 269:1117-1123.

Christie BR, Eliot LS, Ito K, Miyakawa H, Johnston D (1995) Different $\mathrm{Ca}^{2+}$ channels in soma and dendrites of hippocampal pyramidal neurons mediate spike- induced $\mathrm{Ca}^{2+}$ influx. J Neurophysiol 73:2553-2557.

Chuhma N, Ohmori H (1998) Postnatal development of phase-locked high-fidelity synaptic transmission in the medial nucleus of the trapezoid body of the rat. J Neurosci 18:512-520.

Doughty JM, Barnes-Davies M, Rusznak Z, Harasztosi C, Forsythe I D (1998) Contrasting $\mathrm{Ca}^{2+}$ channel subtypes at cell bodies and synaptic terminals of rat anterioventral cochlear bushy neurones. J Physiol (Lond) 512:365-376.

Elezgarai I, Benitez R, Mateos JM, Lazaro E, Osorio A, Azkue JJ, Bilbao A, Lingenhoehl K, Van der Putten H, Hampson DR, Kuhn R, Knopfel T, Grandes P (1999) Developmental expression of the group III metabotropic glutamate receptor mGluR4a in the medial nucleus of the trapezoid body of the rat. J Comp Neurol 411:431-440.

Forsythe ID, Tsujimoto T, Barnes-Davies M, Cuttle MF, Takahashi T (1998) Inactivation of presynaptic calcium current contributes to synaptic depression at a fast central synapse. Neuron 20:797-807.

Iwasaki S, Takahashi T (1998) Developmental changes in calcium channel types mediating synaptic transmission in rat auditory brainstem. J Physiol (Lond) 509:419-423.

Katz B (1969) The release of neural transmitter substances Liverpool, UK: Liverpool UP.

Katz LC, Callaway EM (1992) Development of local circuits in mammalian visual cortex. Annu Rev Neurosci 15:31-56.

Komuro H, Rakic P (1993) Modulation of neuronal migration by NMDA receptors. Science 260:95-97.

Luebke JI, Dunlap K, Turner TJ (1993) Multiple calcium channel types control glutamatergic synaptic transmission in the hippocampus. Neuron 11:895-902.

Miljanich GP, Ramachandran J (1995) Antagonists of neuronal calcium channels: structure, function and therapeutic implications. Annu Rev Pharmacol Toxicol 35:707-734.

Mintz IM, Adams ME, Bean BP (1992) P-type calcium channels in rat central and peripheral neurons. Neuron 9:85-95.
Mogul DJ, Adams ME, Fox AP (1993) Differential activation of adenosine receptors decreases N-type but potentiates P-type $\mathrm{Ca}^{2+}$ current in hippocampal CA3 neurons. Neuron 10:327-334.

Mouginot D, Bossu J-L, Gähwiler BH (1997) Low-threshold $\mathrm{Ca}^{2+}$ currents in dendritic recordings from Purkinje cells in rat cerebellar slice cultures. J Neurosci 17:160-170.

Omote K, Kawamata M, Satoh O, Iwasaki H, Namiki A (1996) Spinal antinociceptive action of an $\mathrm{N}$-type voltage-dependent calcium channel blocker and the synergistic interaction with morphine. Anesthesiology 84:636-643.

Onodera K, Takahashi T (1996) Developmental changes in GABAergic IPSCs recorded from rat thalamic neurons in slice. Neurosci Res Suppl 20:S31.

Plant TD, Schirra C, Katz E, Uchitel OD, Konnerth A (1998) Single-cell RT-PCR and functional characterization of $\mathrm{Ca}^{2+}$ channels in motoneurons of the rat facial nucleus. J Neurosci 18:9573-9584.

Pouzat C, Hestrin S (1997) Developmental regulation of basket/stellate cell-Purkinje cell synapses in the cerebellum. J Neurosci 17:9104-9112.

Regehr WG, Mintz IM (1994) Participation of multiple calcium channel types in transmission at single climbing fiber to Purkinje cell synapses. Neuron 12:605-613.

Rosato Siri MD, Uchitel OD (1999) Calcium channels coupled to neurotransmitter release at neonatal rat neuromuscular junctions. J Physiol (Lond) 514:533-540.

Scholz KP, Miller RJ (1995) Developmental changes in presynaptic calcium channels coupled to glutamate release in cultured rat hippocampal neurons. J Neurosci 15:4612-4617.

Stefani A, Spadoni F, Bernardi G (1998) Group III metabotropic glutamate receptor agonists modulate high voltage-activated $\mathrm{Ca}^{2+}$ currents in pyramidal neurons of the adult rat. Exp Brain Res 119:237-244.

Steriade M, Llinas RR (1988) The functional states of the thalamus and the associated neuronal interplay. Physiol Rev 68:649-742.

Takahashi T, Momiyama A (1993) Different types of calcium channels mediate central synaptic transmission. Nature 366:156-158.

Takahashi T, Forsythe ID, Tsujimoto T, Barnes-Davies M, Onodera K (1996) Presynaptic calcium current modulation by a metabotropic glutamate receptor. Science 274:594-597.

Takahashi T, Kajikawa Y, Tsujimoto T (1998) G-protein-coupled modulation of presynaptic calcium currents and transmitter release by a $\mathrm{GABA}_{\mathrm{B}}$ receptor. J Neurosci 18:3138-3146.

Umemiya M, Berger AJ (1994) Activation of adenosine $A_{1}$ and $A_{2}$ receptors differentially modulates calcium channels and glycinergic synaptic transmission in rat brainstem. Neuron 13:1439-1446.

Vigers AJ, Pfenninger KH (1991) N-type and L-type calcium channels are present in nerve growth cones. Numbers increase on synaptogenesis. Dev Brain Res 60:197-203.

Westenbroek RE, Hell JW, Warner C, Dubel SJ, Snutch TP, Catterall WA (1992) Biochemical properties and subcellular distribution of an N-type calcium channel $\alpha 1$ subunit. Neuron 9:1099-1115.

Westenbroek RE, Hoskins L, Catterall WA (1998) Localization of $\mathrm{Ca}^{2+}$ channel subtypes on rat spinal motor neurons, interneurons, and nerve terminals. J Neurosci 18:6319-6330.

Wheeler DB, Randall A, Tsien RW (1994) Roles of N-type and Q-type $\mathrm{Ca}^{2+}$ channels in supporting hippocampal synaptic transmission. Science 264:107-111.

Wu L-G, Borst JGG, Sakmann B (1998) R-type $\mathrm{Ca}^{2+}$ currents evoke transmitter release at a rat central synapse. Proc Natl Acad Sci USA 95:4720-4725.

Wu L-G, Westenbroek RE, Borst JGG, Catterall WA, Sakmann B (1999) Calcium channel types with distinct presynaptic localization couple differentially to transmitter release in single-calyx synapses. J Neurosci 19:726-736. 